\title{
Comparative Feeding of Two Concentrate Diets on Voluntary Feed Intake and Growth Performance of Pyar Sein Calves in Myanmar
}

\author{
K.S. Win ${ }^{1 *}$, S. Khant ${ }^{2}$, T.H. Soe ${ }^{2}$, W.T. Myint ${ }^{2}$, Z.T. Kyaw ${ }^{1}$, K.K. \\ $\mathrm{Lay}^{3}$
}

${ }^{1}$ Livestock Demonstration Farms, University of Veterinary Science; ${ }^{2}$ Undergraduate students of University of Veterinary Science; ${ }^{3}$ Department of Animal Science, University of Veterinary Science, Yezin, Nay Pyi Taw, 15013, Myanmar

*Corresponding author- e-mail: kyawsanwinksw08@gmail.com; Ph: +959797684066, Fax: +95 673416528

Journal of Livestock Science (ISSN online 2277-6214) 11:122-126

Received on 21/5/2020; Accepted on 23/7/2020

doi. 10.33259/JLivestSci.2020.122-126

\begin{abstract}
In Myanmar, Napier grass (Pennisetum purpureum) is considered as good palatable grass for crossbred dairy and local cattle and has been used extensively. The objectives of this study were to evaluate the potential Lablab bean husk (LLBH) for local calves to get maximum growth performance and optimum feeding cost by homemade concentrate in dry season. Ten male Pyar Sein calves with an average age of nine months were used in this experiment. All calves were individually weighed and divided equally into two treatments. Treatment 1 was fed with homemade concentrate while treatment 2 calves were fed commercial concentrate and both treatments were given the same NGS. There were no significant differences occurred in average dry matter intake of NGS (nDMI), average total dry matter intake (tDMI), the average final weight, average weight gain (WG), average daily weight gain (ADG) and average feed conversion ratio (FCR) between the treatments. However, dry matter intake of NGS (\%BW) and total dry matter intake (\% BW) showed a significant difference. The treatment 1 calves fed homemade concentrate showed greater nDMI and tDMI. As an aspect of economic evaluation, feeding agricultural and industrial by-products as a concentrate feed is economically viable for local smallholder farmers.
\end{abstract}

Keywords: Pyar Sein calves; Lablab bean husk (LLBH); homemade concentrate; feed intake; growth performance 


\section{Introduction}

Various roughages or forages are applicable for cattle feeding in tropical countries; however most of cattle roughages are low nutrient crop residues, namely rice straw, corn stover, sorghum stover, and cut-andcarry grasses from along roadsides. Napier grass was generated originally from sub-Saharan tropical Africa (Clayton et al., 2013). It has been introduced as forage into most tropical and subtropical countries worldwide. It is a very versatile species that can be planted under a variety of conditions and systems such as dry or wet conditions, smallholder or large scale farmers. It is valuable forage and very famous throughout the tropics, particularly in cut-and-carry systems (FAO, 2015). Thus, Napier grass is now considered as a good palatable grass for crossbred dairy cows and local cattle along with other grasses in Myanmar.

Grasses in the tropics and subtropics grow quickly during period of much precipitation and high temperature, lead to mature grasses consisting of high levels of cell wall constituents. Against the seasonal scarcity of roughage for livestock in the area which has a long dry season, the grass must be stored. Drying the grass is difficult because grasses grow in a season which has much precipitation and; therefore one storage method is silage making. Ensiled forages are important sources of roughage that are fed throughout the year during the periods of restricted seasonal availability of pasture for the grazing animals (Wilkinson and Davies, 2013). The productivity of ruminants in South-East Asia is hindered by the shortage of feed availability for both quantity and quality, particularly in a dry season. Feeding of local cattle with conserved forages has become an important feeding strategy, however, silage making and feeding of silage from Napier grass is not still conventional in tropical regions including Myanmar.

Protein is the main component of ruminant ration and a suitable crude protein (CP) level is very important (Bailey et al. 2008). Previous studies indicated that feeding a Napier grass at the recommended stage of maturity does not support high animal performance (Anindo and Potter, 1986; Muinga et al., 1995). To promote the efficient feeding of Napier grass, a conventional or commercial concentrate with high CP is needed (Tessema and Baars, 2004; Aung Ko Ko Zaw et al., 2017). However, commercial concentrates are too expensive for smallholder farmers. Agricultural by-products or industrial by-products are considered as an alternative feed for ruminant as for economic and environmental concerns. Protein supplements like sesame meal, peanut meal, cottonseed meal and sunflower meal and energy supplement such as rice bran, wheat bran, corn, molasses, lablab bean husk and chick peas husk are available regionally in Myanmar (Andy et al., 2018). An easily digestible fiber, lablab bean husk (LLBH) is a by-product, which is leftover when fried bean seeds are made from bean. Lablab bean husk is the main residue of fried bean seed product, and it is considered as waste, which is mostly dump and burn. It could also used as feed for ruminants due to its nutritional value and excellent functional properties (Tin Ngwe, 2003; Kyaw Min Htay, 2015). There are a considerable number of fried bean seed factories in the central part of Myanmar, which are mostly located in peri-urban and rural areas. A large portion of LLBH waste is used as feed for ruminants. The use of LLBH as ruminant feed is viable and economical to smallholder farmers who live near factories or suppliers, due to the relatively low price of this by-product. However, there are limited data on lablab bean husk utilisation and on its long-term feeding impact on the growth responses in local cattle.

Myanmar local cattle have smaller body size and a poor growth rate than temperate or Bos taurus beef cattle. Consequently, the $\mathrm{CP}$ requirement of Myanmar local cattle may not be similar as those recommended by national research council (NRC, 1996). Recently, by-products of agriculture or industries have been extensively used to fatten cattle in Myanmar. Therefore, there is a clear need to determine the CP level of concentrates based on low quality feed to facilitate potential cattle production. The aims of this work were to evaluate a potential LLBH for local calves to obtain a maximum growth performance and optimum feeding cost by feeding homemade concentrate in dry season.

\section{Materials and Methods}

\section{Experimental Design, Animal and Diet}

The experiment was conducted at the Livestock Demonstration Farms, University of Veterinary Science, Yezin, Naypyitaw. Ten male local calves (Pyar Sein) of approximately 8 to 10 months of age, with live weight of $140.2 \pm 13.8 \mathrm{~kg}$ were used in this experiment by using student-t test. All calves were individually weighed and allocated randomly and equally (five calves) into two treatment groups for the entire duration of the trial (74 days). All animals were treated for internal and external parasites with Ivermectin (SAMYANG ANIPHARM, SEOUL, KOREA) 14 days prior to experiment.

Group 1 was fed diet 1(homemade concentrate) while group 2 was fed diet 2 (commercial concentrate). The main ingredients of Diet 1 were cottonseed meal and lablab bean (Dolichos lablab) husk (LLBH) and those of diet 2 were corn, palmkernal meal, rice/wheat bran, green bean shell and dried distillers grains (DDGS). The homemade concentrate was formulated only same crude protein level (CP20\%) in accordance with commercial concentrate. Concentrate allowance for each calf was $1 \%$ of live body weight (DM basis) daily and was adjusted biweekly in accordance with any changes to the body weight of the calf. 
Both grouped calves were given the same quality of Napier grass silage (NGS). Napier grass for silage was harvested at the maturity stage of 90 days after planted to get more DM yield. Napier grass was chopped with a chopper machine into the lengths about $2-3 \mathrm{~cm}$. And then, chopped pieces of Napier grass for silage were packed tightly in concrete bunker silo. Air in the bunker silo was withdrawn by means of loader and stored NGS before the starting of feeding trial. Napier grass silages of each calf for everyday were offered ad libitum (110\% of the previous day's intake) in two equal portions. Allowed concentrates fed to each calf at 07:30 am and 3:30 pm, twice daily, in two equal amounts. Water and mineral licks were offered ad libitum. The dry matter (DM) content of NGS, cottonseed meal and LLBH was $28.7 \%, 89.6 \%$ and $89.4 \%$ while crude protein (CP) content of these was $8.16 \%, 26.32 \%$ and $8.20 \%$, respectively, used in this research.

\section{Feeding Trial}

The calves were fed treatment diets for 14 days for the adaptation period before the beginning of data collection. The calves were fed twice a day around 7:30 am and 3:30 p.m. Feed intake of calves was recorded daily and feed consumption was determined weekly to meet the daily requirement. Daily samples of the diet were collected before the morning feeding and were bulked on a weekly basis. Feed refusals were removed from the mangers and weighed before the morning ration was fed. Feeding mangers were always cleaned before a new feed is put to ensure that the new feed was always cleaned and free of mould or fungus. During the feeding trial, each calf was weighed twice a month, between 06:30 and 07:30 am before feeding to calculate an average daily gain (ADG). The ADG was calculated by dividing the initial and final weight differences by the total number of experimental days (74 days).

\section{Analysis of data}

Data on these parameters were subjected to Student's t test (Snedecor \& Cochran, 1994), using repeated measures, at 5\% probability. Data on BW of each calf were also analysed using Student's t test at 5\% probability.

\section{Results and Discussion}

Findings of feed intake and growth performances of Pyar Sein local calves fed diet 1 (homemade concentrate) and diet 2 (commercial concentrate) that was recorded over the feeding trial period are displayed in Table 1. The results showed that claves fed diet 1 had smaller average weight gain $(12.20 \mathrm{~kg})$ and average daily gain $(225.2 \mathrm{~g} /$ day) than calves in diet $2(12.50 \mathrm{~kg}$ and $230.6 \mathrm{~g} /$ day, respectively). However, there was no significant difference in these two parameters between the two concentrate treatments group. This is because quality of silage affects fattening performance regardless of the breed type commented by Cummins et al. (2007).

The quality of silage fed to livestock influences its intake, total feed intake and consequently fattening efficiency (Steen et al., 1998). In the current feeding trial, for dry matter intake of NGS and total dry matter intake of calves, the results were not significant different between groups although diet 1 calves possessed numerically higher average DMI of NGS (2.2 kg/day) and average total DMI (3.6 kg/day) than calves in diet 2 $(1.9 \mathrm{~kg} /$ day and $3.2 \mathrm{~kg} / \mathrm{day})$. It is commonly accepted that Napier grass yields increase and nutritive value declines with increasing maturity (Spitaleri et al., 1995). The recommended week for Napier grass intended for silage making was 8-10 weeks for hybrid Pennisetums (Spitaleri et al., 1995). Manyawu et al. (2003) suggested that Pennisetums should be harvested between 6 and 7 weeks, to increase DM content and optimum herbage production without seriously affecting nutritive value and water soluble carbohydrate content. Nevertheless, silage made from immature Pennisetum is undesirable due to high buffering capacity, poor conservation and the high concentrations of acetate that forms in the silage (Woodard et al. 1991). However, in terms of dry matter intake expressed as $\%$ of body weight $(\mathrm{BW})$, the data observed that calves fed diet 1 showed significantly greater average dry matter intake of NGS $(1.5 \% \mathrm{BW})$ and average total dry matter intake $(2.5 \% \mathrm{BW})$ than calves fed diet $2(1.3 \%$ and $2.2 \%)$. This means that the intake of silage was clearly affected by given concentrates. Because all claves received the same amount of concentrates but different kinds of concentrate, total DM intake showed the same pattern as DM intake from silage. This variation might have been caused by ingredients of concentrate. One of the ingredients in homemade concentrate is lablab bean husk, readily digestible fiber source. The lablab bean husk (LLBH) is most easily digested or fermented in the rumen (Tin Ngwe, 2003). Feeding easily fermentable fiber sources as energy supplement can increase forage intake of ruminants observed by Orskov (1991). Kyaw Min Htay (2015) found that higher levels of LLBH supplementation showed the greater growth performance of goat. The effect was possible by increasing total viable bacteria and cellulolytic bacteria that promote fiber degradation of forage in the rumen of goat supplemented with sugar-beet pulp, an easily digestible fiber (Masuda et al., 1999).

Feed conversion ratio (FCR) is one of the important measurements, which is standardized in growth performance of animal. FCR is a measure of how conversion efficiency of livestock by animal feed to desired outputs such as eggs, milk, meat and wool. Based on Table 1, there is no significant effect on FCR of calves fed two different concentrates. Every farmer desires a low FCR because a low FCR means lower feed cost. 
Table 1 Feed intake and growth performance of Pyar Sein calves fed two concentrate Diets

\begin{tabular}{|l|c|l|l|}
\hline Average & Diet 1 & Diet 2 & P-value \\
\hline Initial body weight $(\mathrm{kg})$ & & & \\
\hline Final body weight $(\mathrm{kg})$ & 141.8 & 138.6 & \\
\hline Weight gain (kg) & 154.0 & 151.6 & \\
\hline Average daily gain (ADG) (g/day) & 12.2 & 12.5 & $\mathrm{NS}$ \\
\hline Dry matter intake of NGS (kg) & 225.2 & 230.6 & $\mathrm{NS}$ \\
\hline Total dry matter intake (kg) & 2.2 & 1.9 & $\mathrm{NS}$ \\
\hline Dry matter intake of NGS & 3.6 & 3.2 & $\mathrm{NS}$ \\
\hline$(\%$ of BW) & 1.5 & 1.3 & $* *$ \\
\hline Total dry matter intake & & & \\
\hline$(\%$ of BW) & 2.5 & 2.2 & $* *$ \\
\hline Feed conversion ratio (FCR) & & & \\
\hline
\end{tabular}

Diet 1: homemade concentrate, Diet 2: commercial concentrate, NGS: Napier grass silage,

BW: body weight, NS: non-significance $*: \mathrm{P}<0.05, * * \mathrm{P}<0.01$

Table 2. Mean values of concentrate feed cost

\begin{tabular}{|c|c|c|c|c|c|c|c|}
\hline $\begin{array}{l}\text { Treatment } \\
\text { Group }\end{array}$ & $\begin{array}{l}\text { Ingredients of } \\
\text { concentrate }\end{array}$ & $\begin{array}{l}\text { Proportions of } \\
\text { Ingredients }(\%)\end{array}$ & \begin{tabular}{|l|} 
Crude \\
protein \\
$(\mathrm{CP})(\%)$
\end{tabular} & $\begin{array}{l}\text { Concentrate } \\
\text { Cost }(\mathrm{MMK} / \mathrm{kg})\end{array}$ & $\begin{array}{l}\text { Concentrate } \\
\text { Given } \\
\text { (kg/calf) }\end{array}$ & $\begin{array}{l}\text { Concentrate Cost } \\
\text { (MMK/calf/day) }\end{array}$ & P-value \\
\hline Diet 1 & $\begin{array}{l}\text { Cottonseed meal } \\
\text { Lablab bean husk }\end{array}$ & $\begin{array}{l}66.67 \\
33.33 \\
\end{array}$ & 19.7 & 327 & 1.45 & 474.15 & \multirow[t]{2}{*}{$*$} \\
\hline Diet 2 & $\begin{array}{l}\text { Palmkernal meal, } \\
\text { Corn, Rice/Wheat } \\
\text { bran, Green bean } \\
\text { shell, Dried Distiller } \\
\text { Grains }\end{array}$ & ND & 20.0 & 456 & 1.42 & 647.25 & \\
\hline
\end{tabular}

MMK: Myanmar Money Kyats; ND: not determined; *: $p<0.05$

From the viewpoint of economic evaluation which was calculated based on the current animal feed prices (Table 2) showed that the costs for homemade concentrate and commercial concentrate as an animal feed were MMK327/Kg and MMK 456/Kg, respectively. Cost of making homemade concentrate is lower than $28.3 \%$ (MMK129) than that of commercial concentrate. The feeding cost (474.15 MMK/calf/day) of homemade concentrate fed each calf per day was significantly lower than $(647.52 \mathrm{MMK} /$ calf/day) the cost of commercial concentrate in this feeding trial. As its nutritive value, LLBH is a relatively cheap feed resource because it is considered as an industrial waste which is often incinerated due to fire danger. Livestock farms in the areas of fried bean seed processing factories would benefit from the use of the low-cost feeding of LLBH. Lablab bean husk as a supplemental feed ingredient in the diet of calf may help farmers to profit from this by-product, whose utilization could help sustain the factories and minimize the environmental pollution. Since the feed intake of calves is affected by concentrate supplement including LLBH, further research is necessary on the growth performances of this agro-industrial by-product by animals tested on the different levels of concentrate and different basal roughages.

\section{Conclusion}

Feeding of homemade concentrate did not show adverse effect on ADG, DMI and FCR in local Pyar Sein calves. It would be useful from the point of view of low cost animal feeding or reduction of the residue.

\section{Acknowledgement}

The authors wish to express their gratitude to JAPFA COMFEED MYANMAR Pte.Ltd. for providing research grant to conduct this experiment.

\section{Conflict of Interests}

The homemade concentrate and funding were supported by JAPFA COMFEED MYANMAR Pte.Ltd., but no person from JAPFA COMFEED MYANMAR Pte.Ltd. was involved at any stage of the study and publication. The authors declare that they have no competing interest.

\section{Authors' participants}

All authors participated to the study concept and design. Material preparation, data collection and analysis were performed by KSW, SK, THS, ZTZK and KKL. The first draft of the manuscript was written by KSW; ZTZK and KKL revised the manuscript. All authors read and approved the final manuscript. 


\section{References}

1) Andy DH, Ai Thanda Kyaw, Thet Khaing, 2018. Beef cattle production system capacity considerations for improved food security: A case study in Myanmar.

2) Anindo DO, Potter HL, 1986. Milk production from Napier grass (Pennisetum purpureum) in zero-grazing feeding systems. East African Agricultural and Forestry Journal 52: 106-111.

3) Aung Ko Ko Zaw, Kyaw Chan Nyein, Lae Lae Swe, Mya Myint Zu, Thwe Thwe Zun, Nay Thinzar Win Nyunt, Shwe Sin Soe Htet, Win Yadanar Htet, Thet Hmue Htet, 2017. Effect of concentrate supplementation on growth performance of local breed cattle fed a basal diet of Napier grass. Graduation Thesis. Group7. University of Veterinary Science, Yezin, Myanmar.

4) Bailey CR, Duff GC, Sanders SR, Treichel JL, Baumgard LH, Marchello JA, Schafer DW, McMurphy CP, 2008 . Effects of increasing crude protein concentrations on performance and carcass characteristics of growing and finishing steer and heifers. Animal Feed Science and Technology. 142:111-120.

5) Clayton WD, Govaerts R, Harman KT, Williamson H, Vorontsova M, 2013. World checklist of Poaceae. Richmond, UK:Royal Botanic Gardens, Kew.

6) Cummins B, Keane MG, O'kiely P, Kenny DA, 2007. Effect of breed type, silage harvest date and pattern of offering concentrates on intake, performance and carcass traits of finishing steers. Crop Science 46 : 149-168.

7) Food and Agriculture Organization (FAO), 2015. Grassland Index. A searchable catalogue of grass and forage legumes. FAO, Rome, Italy.

8) Kyaw Min Htay. 2015. Effect of concentrate supplementation on growth performance of local breed cattle fed a basal diet of Napier grass. PhD Thesis, University of Veterinary Science, Myanmar.

9) Manyawu GJ, Chakoma C, Sibanda S,Mutisi C, Chakoma IC, 2003. The effect of harvesting interval on herbage yield and nutritive value of Napier grass and hybrid Pennisetums. Asian Australasian Journal of Animal Sciences 16: 996-1002.

10) Masuda Y, S Kondo, M Shinjo and Goto J, 1999. Effect of sugar beet pulp supplementation on fiber degradation of grass hay in the rumen of goats. Asian-Australasian Journal of Animal Sciences 12: 186-188.

11) Muinga, RW, Thorpe W, Topps JH, 1995. The effects of supplementation of Leucaena leucocephala and maize bran on voluntary intake, digestibility, live-weight change and milk yield of Bos indicus x Bos taurus dairy cows and rumen fermentation in steers offered Pennisetum purpureum ad libitum in the semi-humid tropics. Animal Science 60: 13-23.

12) National Research Council (NRC), 1996. Nutrient requirements of beef cattle. $7^{\text {th }}$ ed. National Academy Press, Washington, DC.

13) Orskov ER, 1991. Energy Nutrition in Ruminant. Orskov ER and Ryle M (eds) Elsevier, NY, pp.84-101.

14) Snedecor GW, Cochran WG, 1994. Statistical methods. $8^{\text {th }}$ ed. Ames: Iowa State University Press.p593.

15) Spitaleri RE, Sollenberger LE, Staples CR, Schank SC, 1995. Harvest management effects on ensiling characteristics and silage nutritive value of seeded Pennisetum hexaploid hybrids. Postharvest Biology and Technology 5: 353-362.

16) Steen RJW, Gordon FJ, Dawson LER, Park RS, Mayne CS, Agnew RE, Kilpatrick DJ, Porter MG, 1998. Factors affecting the intake of grass silage by cattle and prediction of silage intake. Animal Science Journal 66: 115-127.

17) Tessema Z, Baars RMT, 2004. Chemical composition, in virto dry matter digestibility and ruminal degradation Napier grass (Pennisetum purpureum Schumacher) mixed with different level of Sesbania sesban (L). Merr. Animal Feed Science and Technology 117: 29-41.

18) Tin Ngwe.2003. The effect of lablab bean (Dolichos lablab) husk, as an alternative source of easily digestible fiber, compared with Chickpea (Cicerarietinum) husk on rice straw digestion and ruminal characteristics in sheep. Ph.D Thesis, Division of Animal Science, Graduate School of Agriculture, Hokkaido University, Japan.

19) Wilkinson JM, Davies DR, 2013. The aerobic stability of silage: Key findings and recent developments. Grass and Forage Science 68: 1-19.

20) Woodard KR, Prine GM, Bates DT, 1991. Silages characteristics of Elephant grass as affected by harvesting frequency and genotype. Agronomy Journal 83: 547-551. 